\title{
Construction of University-Enterprise Talent Cultivation Mode in E-Commerce Industry Base Based on the Learning Map Theory System-- Take Xi'an International Trade \& Logistics Park as an Example
}

\author{
Jiayi Zeng \\ Xi’an Fanyi University, Shaanxi Province, China,710105
}

Keywords: Learning map theory, E-commerce, Industrial base, Talent training model

\begin{abstract}
Learning map theory system is recognized as a talent training method. This approach is featured by "SMP", which means Systemic(S), Modular (M), and Practical (P). This is a good combination of needs and training in order to achieve the training target. Moreover, it can better satisfy the practical needs of the electronic commerce industry base for the double creative talents, so that the training effect can be more easily guaranteed. This paper is on the basis of this theory, and take one of the national e-business demonstration bases -- Xi' an International Trade \& Logistics Park as an example. It takes the learning map theory system as the thinking tool, gives full play to the role of the talent service center in the industrial base, and makes it as a bridge between the cooperation school and the enterprise in the base. Based on the understanding of competency requirements and career development needs of enterprises as well as the integration of university teaching system, it will make students have a clear direction for business requirements and their career development. Moreover, it is possible to make the enterprise have more efficient employees and make the e-commerce industry base more dynamic.
\end{abstract}

\section{Introduction}

In the Ministry of Commerce's Guidance on Further Promoting the Construction of the National E-commerce Demonstration Base, on January 17, 2017, Chinese Ministry of Commerce points out one of the main tasks in the construction of the national e-commerce industry demonstration base during the 13th five-year plan period is to bring up the talents of double creative. And the current talent service center of e-commerce industry base does more work to provide human resources protection. Such as household registration, children's admission assistance, housing subsidies, etc. Organize the existing technical personnel of the enterprise to participate in the national and city recognized e-business training. The method is simple and the function needs to be improved. There is a big gap between training and the requirements of the 13th five-year plan. The problem of human resource is common in the enterprise of electronic commerce industry base. Employees are looking for more personal skills rather than job matching and career development. Employee training tends to be more autonomy, more randomness, less planning and systematicness. Therefore, there is a certain gap between the current situation and demand of human resources capability in the industrial base.

\section{Overview of learning map theory}

\subsection{Learning map theory}

The learning map is based on the strategic map theory of Robert S. Kaplan and David Norton. Based on the competency model, a complete set of learning activities and a series of learning courses are designed. It makes education resources match with the educated professional development, and find the path of personal learning development scientifically and objectively. The learning map can be divided into three categories: group goal, overall target and key position target. The goal of the group is to set up training courses with niche targets, and the main target of the audience will be the managers of the enterprise. The overall goal is to train all personnel. The 
objective of the post is to conduct targeted professional training based on the position ability. In the drawing of learning map, the requirement target is to build the competency model, match the position and ability, build the ability based learning resource base, and make effective map rendering.

\subsection{The function of learning map theory}

Learning map theory is one kind of talent cultivation system planning tool, which can be systematic, periodical, long-term and targeted to train the personnel training system. Its main functions include the following aspects.

\subsubsection{Learning map is a bridge for training lecturer management and talent cultivation}

On the one hand, training instructors understand the students' needs and goals by learning map theory. On the other hand, students can plan their career future through learning map theory, and gradually realize their life goals through training. The two parts are linked and connected, so that the talent cultivation target can be realized.

The learning map provides an objective, authentic, targeted evaluation of needs and a complete curriculum system. The learning map theory system is designed based on the requirement. It can systematically and comprehensively evaluate the value of trainees' training. It can overall measure of student ability quality level, stage for students to study plan and career planning step by step. Moreover, it can build long-term planning for students' grow, specific training content, and make every stage of the evaluation and summary in order to gradually realize the goal of students' learning and life goals.

\subsubsection{Learning maps can improve the enthusiasm of talents and accelerate the growth of talents}

The learning map theory system can dig deep into the needs of trainees and evaluate the disturbing factors in the process of talent cultivation. It can objectively evaluate the interference factors in the process of talent cultivation, and use competency model to tailor curriculum and growth plan for trainees. Moreover, it can provide fresh training content, so that every student can feel the power brought by knowledge, improve the learning enthusiasm, and speed up the ability and speed of knowledge mastering.

\section{Overview of Xi’an International Trade \& Logistics Park}

Xi'an International Trade \& Logistics Park as the intersection node of western development, "One Belt and One Road" and "Silk Road”, it has become the bridgehead of economic development in Shanxi and Xi 'an. Under the policy guidance of the central government's industrial structure adjustment and regional function optimization, Shanxi provincial committee and Xi'an municipal party committee takes Xi'an International Trade \& Logistics Park as the test base to establish a modern service function benchmark.

Xi'an International Trade \& Logistics Park is an important transportation hub in Xi'an city of Shanxi province. It is located in the northeast of the main urban area of $x i$ 'an, at the intersection of the Ba River and the Wei River delta. The construction area is 89.89 square kilometers and the total control area is 120 square kilometers. It is the key distribution base of the strategic planning and the Silk Road economic belt. In Shanxi provincial government and Xi'an city government's overall planning blueprint, Xi'an International Trade \& Logistics Park as the integrated construction base of "port - zone - city". Its function is not only limited to the logistics distribution service, but to make it into a new functional urban area with internationalization, modernization, integration and service. Xi'an International Trade \& Logistics Park has already constructed three functional platforms of comprehensive bonded zone, railway container center station and highway port. It realizes the railway line service port of One Belt and One Road. It is the transit hub of central Asia, and it is the "Internet +" service base of cross-border e-commerce industry park. It uses the Internet and information technology to realize seamless connection of information services in international and 
domestic ports.

The state attaches great importance to the development of Xi'an International Trade \& Logistics Park since its establishment. It has been successively won the "National Modern Service Innovation Base", "National Cross-border Trade E-commerce Service Pilot Core Zone", "National Advertising Industrial park", "National E-commerce Demonstration Base" and other 9 national brands. For three consecutive years, it won the honorary titles of "China Logistics Demonstration Park" and " The most influential area of Shanxi economy ". Moreover, as the president unit of the port association of China port association, Xi'an International Trade \& Logistics Park continuously improves the influence and radiation force of the park, and the function of the port is gradually revealed.

$\mathrm{Xi}$ 'an international port area is an important bridgehead for the western development of Shanxi province. The port area plan is unified with the western economic development plan and the western development strategy. It became the important logistics evacuation base of western economy construction and the road of China's Silk Road and the Maritime Silk Road at the same time. In the national strategic development plan of "One Belt and One Road" and as one of many nodes, Xi'an International Trade \& Logistics Park is experiencing unprecedented development opportunities. As the e-commerce industry base of the port area, it is the time mark break through the regional restrictions with the Internet, and provide modern interconnection services for the transportation and import of Shanxi and Xi'an resources. In this context, Xi'an International Trade \& Logistics Park has the characteristics of targeted talents requirement, and it is in the urgent need of the professional talents introduction.

\section{Talent training mode construction of the university-enterprise cooperation in electronic commerce industry base}

\subsection{Talent cultivation map drawing of e-commerce industry base in Xi'an International Trade \& Logistics Park}

Based on the learning map theory system, this paper firstly analyzes the post structure of Xi'an International Trade \& Logistics Park. We can compile the position sequence according to the principles of business relevance and similarity, model the competency of each position after establishing the ability matching principle, according to the ability requirement to carry on the course matching configuration, and develop phased training programs to provide staff with scientific career advancement planning and learning objectives. For example, Xi'an International Trade \& Logistics Park involves safe environmental protection, project construction, public services, foreign capital for the record, entertainment religious, social relief, medical and health care, education culture, talent employment, social security services, property management services, business tax service, legal services and other business. In the process of information development, the talent cultivation direction of e-commerce industry base is diversified, and the map should be drawn according to the position subdivision.

\subsection{Framework design of school-enterprise cooperation talent training model based on learning map}

In the process of talent cultivation in the e-commerce industry base of Xi'an International Trade \& Logistics Park, we should give full play to the link management between universities and enterprises. We can use the learning map to build the course goals and design the training mode framework based on the cooperation mechanism of enterprise management, collaborative innovation, talent sharing, teacher mutual employment, process sharing and achievement sharing. In the process of cooperation, we should deepen the cooperation model so that the participating subjects can obtain the necessary resources through the university-enterprise talent training platform. Resources in colleges and universities will become part of e-commerce industry base in Xi'an International Trade \& Logistics Park. At the same time, it also let e-commerce industry base of Xi'an International Trade \& Logistics Park become the output base of personnel orientation position. Under the training mode framework of the university-enterprise cooperation learning map, 
enterprise can obtain qualified and excellent talents, colleges and universities can realize the unity of enrollment and job placement services. It will achieve win-win situation on both sides.

\subsection{Talent cultivation implementation strategy}

In the process of talent cultivation, it is necessary to create a seamless cooperation mechanism between universities and enterprises in the e-commerce industry base of Xi'an International Trade \& Logistics Park. The university carries out detailed personnel service special support, the enterprise publishes the post requirement in time. Colleges and universities should carry out personnel training according to the needs of enterprises and special training courses. Give full play to the characteristics of the e-commerce industry, the university talents will enter the Trade \& Logistics Park with projects. This kind of industry-university-research-oriented promotion will support the industrial upgrading and project innovation. Explore the modern apprenticeship system and transform the talent training mode, it is not only to input talents in the park, but also input talents with the spirit of craftsmanship. We need to inherit experience and improve professional quality. Moreover, it is necessary to promote the recruitment of e-commerce and logistics related talents and work allocation integration services. Colleges and universities are based on real projects in personnel training, students can experience real project operations and better put into practice while learning theory. Construct the third-party evaluation mechanism to guarantee the objectivity of the talents quality evaluation during the school-enterprise cooperation will retain talent and provide a career vision for them.

\section{Conclusions}

This paper analyzes the theory and application of learning map and discusses its application in the training mode of school-enterprise cooperation. The conclusion is that the learning map theory system can construct a healthy, complete and ecological talent training system. In the practical application of Xi'an International Trade \& Logistics Park, we can plan the talent training map of the e-commerce industry base in Xi'an International Trade \& Logistics Park that according to the requirements of post facilities and talents in it. Apply the map to establish the framework of the school-enterprise cooperation talent training mode and implement the talent cultivation strategy. It will satisfy the needs of the talents in the port area, build a sound development platform for talents, and achieve win-win results among schools, enterprises and talents.

\section{Acknowledgements}

The study was supported by "Construction of school-enterprise cooperation talents training model of e-commerce industry base based on learning map theory system -- Taking Xi'an international port area as an example, China (Grant No. DZSWCYKT-1701)”.

\section{References}

[1] Xu Ming. Study on the Learning Map System of Young Innovation Talents Based on Competency Model [J]. China Youth Study, 2015(6):35-40

[2] Lin Qiang, Zhang Baozhen, Brief Discussion on "Establishment of Training System for Post Customization" -- Creating a Learning Map with Information Communication Post as an Example [J]. Human Resource Management, 2015(9):52-53

[3] Peng Chujun. Research on the Training Mode of Cross-border E-commerce Talents Based on School-enterprise Cooperation [J]. Market Modernization, 2017(18):150-151

[4] Zhang Chenyu. A study on the Training Mode of Vocational Electronic Business Talents Based on School-Enterprise Cooperation [J]. Education, 2014(12):110-111

[5] Kong Xiaorong, Medical Electronic Commerce Talents Training Mode Based on 
School-enterprise Cooperation. Journal of Medical Informatics, 2015, 3, p.91-94

[6] Zhi Kanmai, Zhang Min, Ma Yonghui. Research and Practice of the Training Mode for the Technical Talents Application in University-enterprise Cooperation -- Taking the Construction of E-commerce Characteristics of Xi'an Translation College as an Example. Journal of Seeking Knowledge Guide, 2015, 1, p.71-73

[7] Gao Yanzi, Qin Jiangtao, Research on Talent Cultivation Based on Talent Quality. China Journal of Commerce, 2014, 10Z, p.219-222 